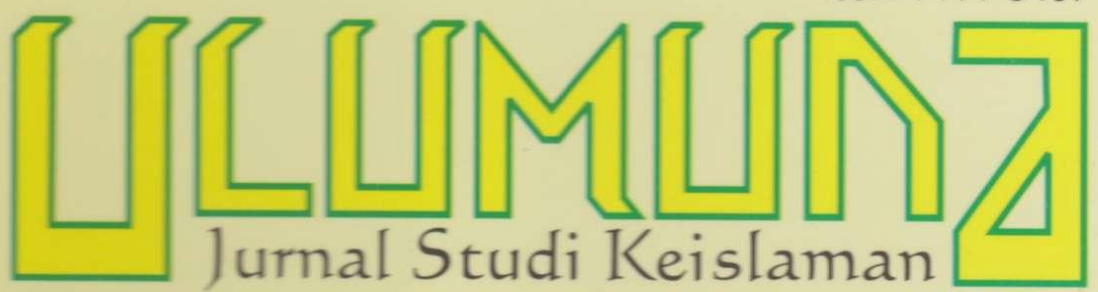

Volume 16 • Nomor 2• Desember 2012

Terakreditası B; SK Dirjen Dikti Kemdikbud Nomor: 56/DIKTI/Kep/2012, Tanggal 24 Juli 2012

REORIENTASI KAJIAN TEOLOGI ISLAM: IKHTIAR KONTRIBUTIF ATASI PROBLEM KEKINIAN Muhammad Rusli

PERGOLAKAN TEOLOGI SYIAH-SUNNI: MEMBEDAH POTENSI INTEGRASI DAN DISINTEGRASI

Slamet Mulyono MEnimbang KontorVERSI PEMAKNAAN KONSEP AHL AL-KITĀB DALAM AL-QUR'AN Zulyadain ECOTHEOLOGY:

TEOLOGI KONSTRUKTIF ATASI KRISIS LINGKUNGAN Abdul Quddus AKU DALAM TUHAN: IMPLIKASI TEOLOGI PROSES PADA ERA KONTEMPORER Suhermanto la'far PERgulatan TEOLOGI SALAFI DALAM MAINSTREAM KEBERAGAMAAN MASYARAKAT SASAK Faizah STUDI KOMPARATIF KONSEP KETUHANAN ISLAM DAN AGAMA ADAM PADA KOMUNITAS SAMIN Mohammad Rosyid KEGALAUAN IDENTITAS:

Dilema Hubungan Komunitas Muslim dan Hindu di BalI Siti Raudhatul Jannah 



\section{DAFTAR ISI}

\section{Pedoman Transliterasi}

\section{3-244 • Muhammad Rusli,}

"Reorientasi Kajian Teologi Islam:

Ikhtiar Kontributif Atasi Problem Kekinian"

245-278 • Slamet Mulyono,

"Pergolakan Teologi Syiah-Sunni:

Membedah Potensi Integrasi dan Disintegrasi"

279-310 • Zulyadain,

"Menimbang Kontorversi Pemaknaan

Konsep Ahl Al-Kitāb Dalam Al-Qur'an"

311-346 • Abdul Quddus,

"Ecotheology:

Teologi Konstruktif Atasi Krisis Lingkungan"

347-374 • Suhermanto Ja'far,

"Aku dalam Tuhan:

Implikasi Teologi Proses pada Era Kontemporer”

375-402 • Faizah,

"Pergulatan Teologi Salafi

dalam Mainstream Keberagamaan Masyarakat Sasak"

403-442 • Mohammad Rosyid,

"Studi Komparatif Konsep Ketuhanan Islam

dan Agama Adam pada Komunitas Samin"

443-464 • Siti Raudhatul Jannah,

"Kegalauan Identitas: Dilema Hubungan

Komunitas Muslim dan Hindu di Bali”

\section{INDEKS}

APENDIKS 


\section{PEDOMAN TRANSLITERASI}

\begin{tabular}{|c|c|c|c|c|c|c|}
\hline 1 & $=$ & $\mathbf{a}$ & & $\dot{\varepsilon}$ & $=$ & $\mathrm{g}$ \\
\hline ب & $=$ & $\mathbf{b}$ & & ف & $=$ & f \\
\hline$ت$ & $=$ & $\mathbf{t}$ & & ق & $=$ & $q$ \\
\hline$\dot{H}$ & $=$ & th & & ك & $=$ & $\mathbf{k}$ \\
\hline ج & $=$ & $\mathfrak{j}$ & & J & $=$ & 1 \\
\hline$\tau$ & $=$ & ha & & s & $=$ & $\mathrm{m}$ \\
\hline$\dot{\tau}$ & $=$ & $\mathbf{k h}$ & & ن & $=$ & $\mathbf{n}$ \\
\hline د & $=$ & d & & و & $=$ & $\mathbf{w}$ \\
\hline ذ & $=$ & dh & & ○ & $=$ & $\mathbf{h}$ \\
\hline Ј & $=$ & $\mathbf{r}$ & & $\varepsilon$ & $=$ & , \\
\hline j & $=$ & $\mathbf{z}$ & & ي & $=$ & $\mathrm{y}$ \\
\hline س س س & $=$ & $\mathbf{s}$ & & & & \\
\hline 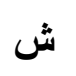 & $=$ & sh & \multicolumn{4}{|c|}{ Untuk Madd dan Diftong } \\
\hline ص & $=$ & ș & i & $=$ & \multicolumn{2}{|c|}{$\bar{a}$ (a panjang) } \\
\hline ض & $=$ & d & إي & $=$ & \multicolumn{2}{|c|}{$\overline{1}$ (i panjang) } \\
\hline b & $=$ & $t$ & 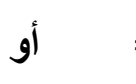 & $=$ & \multicolumn{2}{|c|}{$\bar{u}$ (u panjang) } \\
\hline ظ & $=$ & $\mathrm{z}$ & 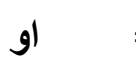 & $=$ & \multicolumn{2}{|c|}{ aw } \\
\hline$\varepsilon$ & $=$ & ‘ & 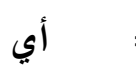 & $=$ & \multicolumn{2}{|l|}{ ay } \\
\hline
\end{tabular}

Contoh penulisan dengan transliterasi:

اعوذ بالله من الشيطان الرجيم (a'üdhu bi al-Lāh min al-shaytān al-rajīm);

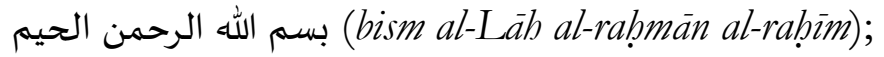

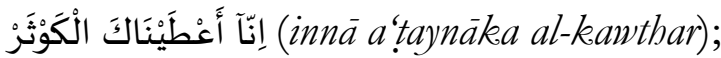

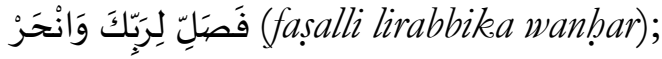

صباح الخير (sabāh al-khayr). 


\title{
PERGOLAKAN TEOLOGI SYIAH-SUNNI: MEMBEDAH POTENSI INTEGRASI DAN DISINTEGRASI
}

\author{
Slamet Mulyono \\ (Fakultas Ushuluddin IAIN Sunan Ampel Surabaya \\ Email:smuliono@gmail)
}

Abstract: Shia-Sunni conflict in Sampang Madura recently, and that happens greased with political strife in Syria to date, suggests that the dynamics of the Shia-Sunni relations is still turbulent. This paper will elaborate aspects of conflict in two major streams in Islam, while also exposing the sides of the similarities between them. There are five issues targeted in this study, namely: the imāmah, the authenticity of the Qur'an, the khilāfah of $A b \bar{u} B a k$, the right to the khilāfah of 'Ali ibn Abi Talib, and the meaning of ahl al-bayt. The authors conclude that the differences in the two streams in the issues range from highly-diametric, put forward by the extreme sects, to the subtle differences and almost in tune, put forward by a moderate sects

Abstrak: Terjadinya konflik Syiah-Sunni di Sampang Madura belum lama ini, dan yang terjadi dengan dilumuri pertikaian politike di Suriah bingga saat ini, menunjukkan bahwa dinamika bubungan Syiab-Sunni masib terus bergolak. Tulisan ini akan mendedah aspek-aspek pertentangan dalam dua aliran besar dalam Islam itu, disamping juga memapar sisi-sisi kesamaan di antara keduanya. Ada lima masalah yang disasar dalam kajian ini, yaitu: imāmah, keotentikan al-Qur'an, khilāfah $A b \bar{u}$ Baker, bak khilāfah atas 'Alì ibn Abì Ṭălib, dan pemaknaan terbadap ahl al-bayt. Penulis menyimpulkan babwa perbedaan dua aliran itu dalam lima hal tersebut merentang mulai dari sangat bersifat diametral, yang dikemukakan oleh sekte-sekte yang ekstrem, hingga perbedaan yang halus dan hampir seirama, yang dikemukakan oleh sekte-sekte yang moderat.

Keywords: Konflike teologi, Syiah, Sunni, imāmah, otentisitas al-Qur'an, khilāfah, ahl al-bayt. 
KONFLIK di Suriah, yang berawal dari soal politik, kemudian menimbulkan berbagai blok kepentingan yang kemudian mengarah pada konflik berdarah antara pihak pemerintah dan pemberontak Suriah. ${ }^{1}$ Fakta terbaru hingga akhir September tahun 2012, korban meninggal sudah mencapai di atas angka 10.000 orang. Rezim Suriah menganut ideologi Syiah Nushairiyah, sebuah sekte Syiah yang ekstrem. ${ }^{2}$ Varian Syiah ini menampilkan aksi cleansing ideology (pembersihan ideologi) terhadap kelompok yang berideologi Sunni. Drama teror, penyiksaan, pembunuhan, pemerkosaan yang mengarah pada kelompok Syiah terhadap para korban yang dikategorikan sebagai kelompok Sunni merupakan fakta baru. Pembunuhan dan penyiksaan secara kejam itu telah dipertontonkan oleh tentara dan milisi Syiah yang memperoleh dukungan rezim Bashar al-Assad, presiden Suriah saat ini. ${ }^{3}$ Tindakan brutal yang mengarah pada pembersihan kelompok Sunni ini ternyata merupakan drama lanjutan yang sudah dilakukan oleh rezim sebelumnya, Hafidh al-Assad, yang tidak lain adalah ayah kandung Bashar al-Assad. Fakta ini menunjukkan adanya konflik yang bernuansa ideologi, disamping bermotif politik dan ekonomi.

Dalam tataran lokal, pengusiran terhadap komunitas Syiah dilakukan oleh warga Sampang Madura karena warga menganggap bahwa ajaran Syiah sangat bertentangan dengan paham Sunni, sehingga secara resmi ulama Madura melarang ajaran Syiah menyebar di Madura. ${ }^{4} \mathrm{Hal}$ ini menunjukkan bahwa antara Syiah dan Sunni sulit untuk dipersatukan keberadaannya. Kajian Badan Intelijen Negara (BIN) menyatakan bahwa potensi konflik antara Syiah dan Sunni di Inonesia begitu besar karena perbedaan yang begitu tajam di antara kedua kelompok itu, ${ }^{5}$ di antaranya orang Syiah tidak wajib salat jum'at selama belum datang seorang imam yang ditunggu (Imam Mahdi al-Muntaz̧ar).

${ }^{1}$ Republika, Selasa, 6 Maret 2012.

'Sulaiman al-Halabi, Täifah al-Nușairiyah Tārikhuhā wa 'Aqāiduhā, (Kuwait: Ad-Dār As-Salafiyah, cet. 2, 1404), 21-26.

${ }^{3}$ Ar-Rohmah.com. diakses 1 April 2012.

4Jawa Pos, Rabu, 4 Januari 2012.

${ }^{5}$ Staf Ahli Bidang Sosial Budaya BIN, Komunitas Syiah di Indonesia. mengantisipasi potensi konflik yang terpendam, Perspektif Historis dan Sosial Budaya, (Jakarta: Badan Inteligen Negara RI, 2008). 
Mereka memiliki kepercayaan bahwa kekhalifahan yang sah adalah 'Ali tetapi direbut oleh Abū Bakr, 'Umar, 'Uthmān ibn 'Affān dan para sabahatnya. ${ }^{6}$ Kepercayaan inilah yang kemudian menjadi bibit permusuhan yang tak berkesudahan.

Dari berbagai kajian di atas menarik untuk mengeksplorasi lebih mendalam tentang dua faham keagamaan (Syiah dan Sunni) itu, mengkaji pokok-pokok ajarannya, pemikiran keagamaannya, dan bagaimana prospek penyatuan antara keduanya berdasarkan persamaan dan perbedaan keduanya. Penelitian ini akan mampu memotret berbagai dinamika gerakan-gerakan Islam, khususnya dinamika dan perkembangan gerakan Islam yang bersifat transnasional. Bahkan secara akademik akan lebih menarik untuk mengeksplorasi serta menguji sejumlah pihak yang menginginkan adanya persatuan Islam meski dengan pokok ajaran yang berbeda, sebagaimana yang sering didengungkan oleh pihak Syiah maupun Sunni.

\section{Genealogi dan Ajaran Syiah}

Sejarah munculnya Syiah tidak lepas dari perdebatan tentang khalifah pengganti Rasulullah. Kalangan Anșār mengklaim golongan merekalah yang berhak memegang amanat itu, sementara kalangan Muhajirin mengklaim sebaliknya. Di pihak yang lain, kelompok yang mendukung 'Ali ibn Abī Ṭālib yang didukung bani Hāshim, Al-Miqdād ibn al-Aswad, Salman alFarisi, Abū Dhar al-Giffāri yang mengkristal muncul ketika akhir pemerintahan 'Uthmān ibn 'Affān, dan berkembang pesat ketika 'Ali ibn Abī Țālib memegang kekuasaan sebagai khalifah.'

Nama Syiah digunakan untuk menunjuk kepada segolongan orang yang loyal pada 'Ali ibn Abī TTālib dan ahl al-bayt serta mereka meyakini bahwa 'Ali adalah orang yang berhak atas imāmah dan khiläfah, baik berdasarkan naș maupun wasiat baik eksplisit maupun implisit bahwa imamah tersebut tidak akan lepas dari anak cucunya sampai hari akhir nanti. ${ }^{8}$

${ }^{6}$ Ibid., 5-6.

7Ṣabir Ṭuaimah, Dirāsāt fi al-Firāq (Riyādh: Maktabah al-Ma‘ārif, 1983), 10 .

${ }^{8} \mathrm{Abu}$ al-Fath Muhammad 'Abd al-Karim ibn Bakr Ahmad alShahrastani, Al-Milal wa al-Nihal (Beirut: Dār al-Fikr, 1976), 146. 
Awalnya, Syiah bukan mazhab dalam konteks keagamaan melainkan muncul sebagai kekuatan politik yang beranggapan bahwa 'Ali ibn Abī Ṭālib adalah seorang yang dirampas kepemimpinannya oleh Abū Bakr, 'Umar, dan 'Uthmān. Namun pada perkembangannya kelompok ini memiliki pandangan keagamaan di bidang akidah dan hukum, yang kemudian berkembang menjadi suatu aliran besar dengan berbagai sekte. ${ }^{9}$

Dalam Syiah dipercayai adanya imämah, dan yang terkenal dengan Itsna 'Ashariyah, (dua belas imam) karena mereka percaya bahwa hanya imam yang paling berhak menjadi pemimpin. Adapun nama-nama imam itu adalah 'Ali ibn Abī Țālib (Amīr alMukminīn), Hasan ibn 'Ali (Hasan al-Mujtaba), Husayn ibn 'Ali (Husayn al-Shahid), 'Ali bin Husayn ('Ali bin Zaynal Ābidīn), Muḥammad ibn 'Ali (Muḥammad al-Baqir), Ja'far ibn Muḥammad (Ja‘far al-Ṣādiq), Mūsā ibn Ja'far ('Ali al-Ridha), Muḥammad bin 'Ali (Mụ̣ammad al-Jawad atau Muḥammad alTāqi), 'Ali ibn Muḥammad (Ali al-Hādi), Hasan ibn 'Ali (Hasan al-Ashkari), dan Muḥammad ibn Hasan (Muḥammad al-Mahdi). Pengikut Syiah beranggapan bahwa imam ke dua belas Muhammad ibn Hasan (Muhammad al-Mahdi) bersembunyi di ruang bawah tanah ayahnya di Samarra dan tidak kembali, serta akan muncul lagi sebagai ratu adil di akhir zaman untuk menegakkan kebenaran. ${ }^{10}$

\section{Pandangan terbadap Imamah}

Syiah, dengan beberapa variannya, memiliki pandangan yang amat khas tentang imāmah, mulai dari yang bersifat wajib hingga sunnah guna membawa kebaikan umum. Syiah memandang bahwa 'Ali ibn Abī Ṭālib tidak berbaiat kepada Abū Bakr karena dia berkeyakinan bahwa dirinya lebih berhak memangku jabatan imamah daripada orang lain, meski dia tetap mengakui keutamaan dan kelebihan Abū Bakr dan tidak menolak haknya untuk menjadi khalifah atas kaum muslimin. ${ }^{11}$ Bahkan di

${ }^{9}$ Musthafa Muhammad al-Shak'ah, Islam bila Madzabib (Jakarta: Gema Insani Press, 1994), 154.

${ }^{10}$ Huzaemah, Perbandingan Madzab (Jakarta: Logos, 1997), 152.

${ }^{11}$ Ali Ahmad As-Salus, Ensiklopedi Sunni Syiah Studi Perbandingan Akidah dan Tafsir, Jilid 1 (Jakarta: Pustaka Al-Kautsar, 2011), 35. 
kalangan Syiah berkeyakinan bahwa 'Ali ibn Abī Ṭālib tidak berbaiat kepada Abū Bakr hingga meninggalnya Fațimah binti Muhammad. Secara umum Syiah berkeyakinan bahwa imāmah merupakan hal yang wajib, dan 'Ali ibn Abī Ṭālib merupakan figur yang pantas. Bahkan persoalan imāmah itu merupakan hak kelompok abl al-bayt yang terlepas ke tangan Abū Bakr dan 'Umar bin Khaț̣̄āb serta berlanjut ke 'Uthmān bin 'Affān.

Menurut Syiah Ithnā 'Ashariyah bahwa seorang imam wajib ma'șum, sehingga ada kepastian bagi orang-orang mukallaf bahwa imam adalah bujjah Allah dan perkataannya adalah firman Allah, sedangkan perkataan Rasulullah dan hukumnya wajib ditaati dan diterima dengan sepenuh hati serta mengembalikan masalah kepadanya dengan yakin dan pasti. ${ }^{12}$

Dasar bagi kaum Syiah tentang wajibnya imam: Pertama, adanya imam merupakan kelembutan dari Allah. Sebab dengan adanya imam maka keburukan akan hilang dan kewajiban akan bisa dilaksanakan. Sementara melakukan keburukan dan meninggalkan kewajiban tidak akan terjadi bila imam masșüm. Kedua, imam merupakan panutan bagi semua syariat. Bila imam tidak ma'sūm maka kita tidak akan selamat dari perbuatanperbuatan buruknya. Sementara di sisi yang lain sebagai imam dia pasti menyeru kebaikan karena dia menjadi panutan yang wajib diikuti. Sebagai panutan, tidak boleh baginya untuk melakukan perbuatan buruk. Ketiga, jika telah tetap ke-ma'sum-an imam dalam lahir, maka mengharuskan pula ke-ma'șm-annya dalam batin. Posisi imam yang memiliki kemuliaan dan keagungan maka mengharuskan dirinya untuk memiliki kemuliaan dalam bathinnya Keempat, seorang imam harus ma'sum sebelum memegang imāmah. Jika tidak, maka menjadikan sebab menjauh darinya dan tiadanya ketenangan kepadanya. Adapun dalil yang mereka suguhkan adalah firman Allah:

Dan (ingatlah), ketika Ibrāhīm diuji Tuhannya dengan beberapa kalimat (perintah dan larangan), lalu Ibrahim menunaikannya. Allah berfirman: "Sesungguhnya aku akan menjadikanmu imam bagi seluruh manusia". Ibrahim berkata: "(Dan saya mohon juga) dari keturunanku". Allah berfirman: "Janji-Ku (ini) tidak mengenai orang yang zalim". (Qs. alBaqarah [2]: 124).

${ }^{12}$ Ibid., 361. 
Katakanlah: "Apakah di antara sekutu-sekutumu ada yang menunjuki kepada kebenaran?” Katakanlah "Allah-lah yang menunjuki kepada kebenaran". Maka apakah orang-orang yang menunjuki kepada kebenaran itu lebih berhak diikuti ataukah orang yang tidak dapat memberi petunjuk kecuali (bila) diberi petunjuk? mengapa kamu (berbuat demikian)? Bagaimanakah kamu mengambil keputusan? (Qs. Yunus, [10]: 35)

Artinya, jika imam yang tidak mașüm, melakukan maksiat dan dosa, maka tidak layak mendakwahkan kepada kebenaran dan sebaliknya, jika seorang tidak melakukan maksiat berarti dia melakukan ketaatan dan umat logis jika taat dan patuh kepadanya.

Menurut pendapat Syiah Imamiyah, dalam masalah ma'sum, bahwa imam menempati posisi nabi sepenuhnya dengan hanya satu perbedaan, yaitu dalam masalah kenabian. Mereka berpandangan bahwa bila tidak ada imam maka umat akan tersesat, maka imam yang menjaga umat dari kesesatan harus orang yang ma'sum. ${ }^{13}$

Kalangan Syiah memiliki prinsip bada' yang meyakini bahwa seorang imam bisa mengetahui hal-hal yang gaib. Sesungguhnya motivasi yang sebenarnya terhadap prinsip bada' ini adalah bahwa Syiah mengkultuskan para imam dan menempatkan mereka di atas posisi manusia serta menisbatkan ke-ma'sum-an dan mengetahui hal yang gaib. Karena itu harus ada jalan keluar jika para imam mereka menceritakan hal yang gaib dan tidak sesuai dengan keadaan yang terjadi. maka jalan keluar itu adalah dengan mengatakan bada'. Dalam kitab al-Kāfi, disebutkan,

Jika kami menyampaikan pada kalian suatu pembicaraan, lalu terjadi seperti yang kami bicarakan, maka katakanlah, "Allah benar." Dan bila kami menyampaikan kepada kalian suatu pembicaraan lalu terjadi kebalikan dari apa yang kami bicarakan, maka katakanlah, "Allah Maha Benar." niscaya kalian diberikan dua pahala. ${ }^{14}$

Dengan adanya bada' ini maka mereka berpendapat bahwa imam-imam mereka mengetahui hal-hal yang gaib. Lalu bila terjadi selain yang disampaikan mereka, maka dikatakan bahwa

${ }^{13}$ Ibid., 367.

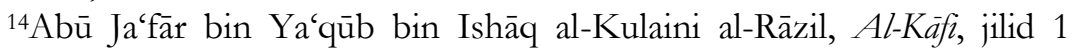
(Teheran: Dar Al-Kutub Al-Islamiah), 369. 
demikian itu telah jelas bagi Allah, dan orang-orang yang membenarkan kebohongan itu diberikan dua pahala.

Sementara itu, Syiah juga memiliki ajaran raj'ah, yang berarti bahwa imam ke-12 mereka yakni Muhammad Al-Mahdi akan muncul kembali (raj'ah) setelah hilangnya. Dia akan menegakkan keadilan setelah terpenuhi berbagai kemaksiatan. Mayoritas kelompok Syiah berpendapat bahwa imam mereka akan kembali lagi setelah meninggal dunia atau dari kegaibannya.

Ajaran Syiah yang lain lagi adalah soal taqiyyah. Keyakinan ini merupakan upaya untuk menolak mudharat atas diri, harta dan kehormatan. Al-'Amili menggambarkannya sebagai berikut:

Seperti kamu berasa di antara kaum yang beragama selain agamamu dan mereka sangat berlebihan dalam fanatisme. Yakni sekiranya kamu tidak sama dengan mereka dalam ucapan dan perbuatan, maka mereka akan sengaja melakukan kemudaratan atau berlaku jahat kepadamu. Maka kamu berperilaku sama seperti mereka sekedar untuk menjaga dirimu dan menghindarkan gangguan kepadamu. Sebab keadaan darurat ditentukan sesuai dengan keadaannya. ${ }^{15}$

Kaum Syiah bersandar pada firman Allah dalam Qs. al-Nahl [16]: 106, "Kecuali orang yang dipaksa kafir padahal hatinya tetap tenang dalam beriman". Sebagaimana kisah Ammar bin Yasir ketika ditangkap orang musyrik dan dipaksa sehingga dia mencaci maki Rasulullah dan menyebut baik tuhan-tuhan mereka, namun hal itu tidak mempengaruhi keimanannya. Kaum Syi'ah juga menggunakan dalil-dalil yang memperbolehkan orang mukmin menampakkan selain yang terdapat dalam hatinya untuk melindungi kehidupannya atau harga dirinya. ${ }^{16}$

\section{Pandangan terbadap Keotentikan Al-Qur'an}

Kaum Syiah menempatkan imam laksana kedudukan Nabi Muhammad dalam ke-ma'șum-an, sifat-sifat dan ilmunya. Bahkan mereka berpendapat bahwa masalah imāmah itu sama dengan nubuwwah (kenabian) dalam banyak hal kecuali dalam masalah wahyu. Kaum Syiah mengakui bahwa para imam tidak menerima

${ }^{15}$ Muḥammad Hasān Zian al-'Amili, Al-Shīah wa al-Tashayyu' (Shaida: Mațba'ah al-'Irfān, 1357), 49 dikutip oleh Al-Salus, Ensiklopedi...., 393.

${ }^{16}$ Muḥammad Husayn al-Kāsyif al-Ghița', Așlu al-Shīah wa Usuluhā, (Kairo: al-Mațba'ah al-Arabiyah, tt), 192. 
wahyu, tetapi mereka berkeyakinan bahwa ilham para imam laksana wahyu dalam menjaga ke-ma'șum-an para imam dari kekeliruan. Sebagian dari kelompok Syiah berkeyakinan bahwa salah seorang malaikat yang selalu berada di sisi Rasulullah yang mengarahkannya dan memberinya petunjuk dan mengajarinya ilmu. Tatkala Rasulullah wafat menghadap Allah, malaikat itu tidak naik ke langit dan tetap tinggal di bumi untuk menunaikan tugasnya mendampingi para imam. ${ }^{17}$

Akidah kaum Syiah tentang imämah begitu besar pengaruhnya terhadap tafsir kalangan Syiah. Di antaranya, kaum Syiah Ja'fariyah berpandangan bahwa imam itu laksana nabi dalam hal ke-ma'sum-an, sifat dan ilmunya. Al-Qur'an yang tertulis dalam mushaf adalah al-Qur'an yang diam, sementara perkataan para imam adalah al-Qur'an yang berbicara. ${ }^{18}$ Mereka mengutip perkataan 'Ali ibn Abī Ṭālib yang mengatakan:

Itulah al-Qur'an. Mintalah dia untuk berbicara, tidak mungkin dia akan berbicara. Saya akan memberitahukan kepada kalian. Sesungguhnya di dalamnya ada ilmu yang telah lalu dan ilmu yang akan datang hingga hari kiamat, dan dia akan menghakimi urusan di antara kalian, dan menerangkan hal-hal dimana kamu sekalian berselisih tentang hal tersebut. Andaikata kalian menanyakan padaku tentang hal tersebut maka akan saya beritahu padamu, karena saya mengajari kalian. ${ }^{19}$

Keterangan ini menunjukkan bahwa menafsirkan al-Qur'an tidak bisa secara langsung merujuk makna secara zabir tetapi harus merujuk pada petunjuk yang dirujuk kepada para imam. Implikasinya adalah bahwa al-Qur'an yang ada adalah al-Qur'an yang diam dan yang bisa menjelaskan maksud Allah adalah para imam. Sehingga tidak boleh seenaknya mengamalkan zabir ayat tanpa merujuk perkataan para imam. ${ }^{20}$

Hal ini menguatkan bahwa wajib bagi seseorang untuk tidak terburu-buru mengambil sebuah kesimpulan dengan sesuatu yang umum sebelum menelusuri yang khusus. Penelusuran yang

${ }^{17} \mathrm{Al}-\mathrm{Salus}$, Ensiklopedi, 550.

${ }^{18} \mathrm{Al}-$ 'Amili, Al-Shi'ah, 45.

${ }^{19} \mathrm{Abū}$ al-Hasan 'Ali bin Ibrāhim Al-Qummi, Tafsìr Al-Qummi (Al-Jazairi: Mațba'ah Al-Najaf, 1386 H)

${ }^{20}$ Muhammad Baqir Șadr, Al-Ma'älim al-Jadidah li al-Ușul, (Najf: Maṭba'ah Nu'mān, 1385H) 76-82, dan Ali Ahmad al-Salus, Fiqh al-Shīāh alImāmiyyah wa Mawāẹi' al-Khiläf Bainahu wa baina al-Madhāhib al-Arba'ah, 48-50. 
khusus itulah mengarah pada pandangan para imam yang merupakan sosok al-Qur'an yang hidup. Karena setelah terputusnya wahyu tidak menafikan adanya kemungkinan nasakh yang dilakukan oleh para imam. Sebab ada kemungkinan Rasulullah telah menitipkan hukum yang menasakh itu pada orang yang mendapat wasiat ('Ali ibn Abī Țālib) dan orang yang dia wasiati selanjutnya hingga sampai waktunya untuk ditampakkan dan disampaikan. Karena di sana telah banyak khabar-khabar yang menyatakan penyerahan agama Allah kepada para imam. ${ }^{21}$

Jumhur ulama Sunni berpandangan bahwa al-Qur'an yang dipegang oleh kaum muslimin, atau disebut sebagai musāf Uthmani merupakan hasil karya para sahabat yang mulia dan terjaga hingga hari kiamat, sebagaimana Firman Allah: "Tidak ada perubahan bagi kalimat-kalimat Allah. yang demikian itu adalah kemenangan yang besar (Qs. Yūnus [10]: 64), dan juga ayat yang lain, yang berbunyi: "Sesungguhnya Kami-lah yang menurunkan al-Qur'an, dan sesungguhnya Kami benar-benar memeliharanya." (Qs. al-hijir [15]: 90).

Kaum Syiah menganggap al-Qur'an telah mengalami perubahan. Bahkan kalangan Syiah Itsna 'Ashariyah merasa kegerahan dengan kesepakatan jumhur ahl al-Sunnah tentang keabsahan al-Qur'an dengan mushaf Utsmani itu. Bahkan kelompok ekstrem Syiah ini mencemooh para sahabat yang mulia khususnya para khulafā' al-rāshidīn sebelum 'Ali ibn Abī Ṭālib, yakni Abū Bakr, 'Umar dan 'Uthmān yang dianggap tidak amanah dalam menerapkan syariat Islam serta dalam penjagaan kitab Allah ini. Bahkan ketiga khalifah tersebut dianggap merampas khilafah dari tangan 'Ali, dan melakukan perubahan terhadap al-Qur'an agar tindakan mereka tidak terbongkar dan tidak tampak hak Ali dan para imam sesudahnya dalam khilafah. ${ }^{22}$

Salah satu kitab yang paling terkenal dari kalangan Syiah yang ekstrem ini adalah kitab Faṣl al-Kitāb fì Tahrîf Kitāb Rabb alArbāb dikatakan bahwa:

${ }^{21}$ Muhammad 'Ali al-Khazimi al-Khurasani, Fawäid al-Ușul 4 (Teheran: Maktabah al-Ṣadr, tt), 247.

${ }^{22}$ Ibid. 
Ini adalah kitab yang lembut dan mulia. Saya tulis kitab ini untuk menyatakan kebenaran bahwa telah terjadi perubahan dalam al-Qur'an, dan saya ungkapkan kecurangan-kecurangan orang yang berbuat jahat dan permusuhan." 23

Untuk menopangnya, kalangan Syiah menunjukkan adanya riwayat perubahan al-Qur'an:

Ketika Muhammad bin Abdullah telah meninggal, dua berhala Quraysh (Abū Bakr dan Umar) melakukan perampokan khilafah. 'Ali ibn Abī Ṭālib mengumpulkan semua Al-Qur'an dan dia letakkan pada kain. Kemudian datang menemui mereka yang saat itu ada di masjid dengan mengatakan, "Inilah kitab Allah. Rasulullah memerintahkan saya untuk memperlihatkan pada kalian agar menjadi bujjah pada hari dimana kita dihadapkan pada Allah di hari Kemudian." Pada saat itulah Fir'aun umat ini dan Namrudnya berkata, "Kami tidak butuh Qur'anmu." Kemudian Abu Quhafah memanggil kaum muslimin dan dia berkata, "Siapa saja yang memiliki al-Qur'an baik satu ayat maupun satu surat maka hendaklaah datang dengan al-Qur'an itu padaku." Maka datanglah kepadanya Abū 'Ubaidah Al-Jarrah, Uthmān bin 'Affān, Sa'ad bin Abi Waqqash, Mu'āwiyyah bin Abū Sufyan, Abdurrahman bin Auf, Ṭalhah bin 'Ubaidillāh, Abū Said al-Khudri, Hasan ibn Thabit dan masih banyak lagi. Mereka mengumpulkan al-Qur'an itu dan membuang semua cacat yang datang dari mereka setelah wafatnya Rasulullah. Oleh karena itu al-Qur'an terlihat tidak sinkron dan tidak padu sedangkan alQur'an yang dihimpun oleh 'Ali ibn Abī Țālib masih ada di Ṣahih alAmr, semoga Allah mempercepat turunnya yang di dalamnya terdapat semua hal, hingga hal yang terkecil. ${ }^{24}$

Demikian keyakinan kaum Syiah. Bahkan ada yang menisbatkan pada Imam al-Ṣādiq yang mengatakan, "Andaikata al-Qur'an ini dibaca sebagaimana saat ia diturunkan, niscaya kalian akan dapatkan nama-nama kami di dalamnya."25

Kalangan Syiah berkeyakinan bahwa telah terjadi perubahan dan penyelewengan dalam al-Qur'an. Menurut Muhammad Sayyid para ahli hadis telah menyatakan kebenaran hadis-hadis mustafidah bahkan hadis-hadis mutawatirah yang secara jelas menunjukkan telah terjadinya perubahan dalam al-Qur'an baik dari segi perkataan, materi, i'rab, maupun pengakuan terhadap

${ }^{23}$ Husain bin Muḥammad Taqi al-Nuri al-Ṭabrāsi, Faṣl al-Kitāb fì Tahrîf Kitāb Rabb al-Arbāb (ttp: Hajar, tt), 6.

${ }^{24}$ Ibid., 9-10.

${ }^{25}$ Ibid., 14. 
kebenaran al-Qur'an itu sendiri. ${ }^{26}$ Bahkan mereka menuduh para sahabat yang mulia dengan sebutan kafir, pemberontak, kejam dan bodoh dengan tujuan agar mereka dianggap sebagai orangorang yang tidak pantas menghimpun al-Qur'an. ${ }^{27}$

Ada pula riwayat al-Khulan̄ yang merujuk pada perkatan Imam al-Ṣādiq yang menyebutkan bahwa sesuangguhnya alQur'an yang dibawa Jibril jumlah ayatnya adalah tujuh belas ribu ayat. ${ }^{28}$ Bahkan penulis kontemporer dari kalangan Syiah dalam Mukaddimah tafsir al-Qummi menyatakan:

Tafsir ini sebagaimana lazimnya tafsir-tafsir terdahulu, mencakup tafsir yang meriwayatkan demikian banyak riwayat yang semuanya mengatakan bahwa mushaf yang kini berada di tangan kita tidak selamat dari adanya perubahan. Perkataan ini tidak sendirian tetapi baik klasik maupun modern, khusus maupun yang umum mengatakan hal yang sama. ${ }^{29}$

Dalam kelompok Syiah ada juga yang berpandangan sebagaimana umumnya ulama Sunni bahwa al-Qur'an tidak mengalami perubahan sebagaimana yang diyakini Syiah Ja'fariyah. Salah satu perkataan Sayyid al-Murtada adalah bahwa al-Qur'an merupakan mukjizat, sumber pengambilan hukum syariah dan hukum-hukum agama. Ulama telah menjaga dan menghafalnya dengan sangat serius hingga mereka tahu segala perbedaan yang ada di dalamnya dari sudut i'rabnya, bacaan (qira'at) dan huruf-huruf serta ayat-ayatnya. Lalu bagaimana mungkin ia telah berubah dan berkurang padahal penjagaan kaum muslimin demikian serius, jujur dan penuh dengan kehatihatian. Intinya adalah al-Qur'an yang dihimpun pada masa Rasulullah sama seperti apa yang ada di tangan kita sekarang. Para sahabat seperti 'Abdullāh ibn Mas'ūd dan Ubay ibn Ka'ab dan sekelompok sahabat datang pada Nabi dan mengkhatamkannya beberapa kali di hadapan Rasulullah. Kelompok Syiah ini berpandangan bahwa pendapat Syiah Imamiah dan Hasyawiah tidak perlu didengarkan karena mereka suka memakai

\footnotetext{
${ }^{26} \mathrm{Al}$-Ṭabrāsi, Faṣl al-Kitāb..., 30.

${ }^{27}$ Ibid., 82.

${ }^{28}$ Ibid., 211.

${ }^{29}$ Mukaddimah Tafsir Al-Qummi, 22.
} 
hadis-hadis da if dengan sangkaan bahwa hadis itu șą̧h, padahal jelas dhaif. 30

Syaikh al-Ṭusi juga mengatakan bahwa pendapat yang mengatakan bahwa di dalam al-Qur'an ada tambahan dan pengurangan, merupakan pendapat yang tidak pantas untuk diungkapkan. Karena perkataan bahwa di dalam al-Qur'an ada tambahan telah disepakati sebagai sesuatu yang batil, begitu pula yang mengatakan bahwa al-Qur'an mengalami pengurangan. Karena al-Qur'an yang ada di tangan kita sudah diketahui keshahihannya, dimana tidak ada yang menentang dan tidak ada pula yang menolak. ${ }^{31}$

\section{Genealogi dan Ajaran Ahlus Sunnah}

Lahirnya kelompok Sunni tidak lepas dari adanya saling tuduh di antara kelompok-kelompok Islam. Mereka saling sesat menyesatkan dan kafir-mengkafirkan, sehingga muncul berbagai perpecahan dalam tubuh umat Islam. Kemunculan Sunni sebagai salah satu respon terhadap fenomena itu. Paham keagamaan ini berpandangan bahwa berpegang teguh dan mengikuti jejak Rasulullah merupakan jalan keluar untuk memperoleh keselamatan, yakni dengan berpegang teguh pada Kitabullah dan Sunnah Rasulullah. ${ }^{32}$

Dalam konteks sosial politik, pergolakan pemikiran Sunni ini tidak terlepas dari adanya perdebatan pemimpin atau pengganti pasca meninggalnya Rasulullah. Dalam pandangan Sunni, pemimpin merupakan tonggak berdirinya agama ini, sehingga kekosongan pemimpin merupakan jurang kehancuran bagi ajaran Islam. Oleh karenanya, perdebatan tentang pentingnya kepemimpinan sudah muncul sejak Rasulullah mengalami sakit yang puncak. Sebuah riwayat menceritakan bahwa Ibn Abbas menanyakan kepada 'Ali ibn Abī Țālib setelah menjenguk Rasulullah yang sakit. Ketika diperoleh jawaban dari mulut Ali bahwa Rasulullah akan sembuh, maka Ibn Abbas menarik tangan Ali dengan mengatakan:

30Sayyid al-Murtadha dalam Mukaddimah, 15.

${ }^{31} \mathrm{Abū} J a$ 'far Muḥammad bin Hasan al-Ṭusi, al-Tibyān I (Najf: 1376), 3.

${ }^{32}$ Yusran Asmuni, Ilmu Taubid (Jakarta: Raja Grafindo Persada, 1996), 121-2. 
"Demi Allah, sesungguhnya engkau lebih mengetahui rona muka Bani Abdul Muthalib saat menjelang kematiannya. Marilah kita bersama-sama menemuinya dan menanyakan kepadanya, kepada siapa urusan ini (imämah) akan diserahkan ? Jika memang itu hak kita, maka kita telah mengetahuinya. Jika hal itu hak orang lain di luar kita, maka kita akan memohon beliau untuk berwasiat kepada kita." Maka Ali menjawab: "Demi Allah, jika kita menanyakan hal itu kepada Rasulullah dan ternyata dia tidak memberikan kepada kita, niscaya orang-orang tidak akan memberikan kesempatan itu bagi kita pada masa mendatang. Aku sendiri, demi Allah, tidak akan menanyakannya kepada Rasulullah."33

Babak sejarah itu menunjukkan bahwa kepemimpinan menjadi pembicaraan yang begitu mendesak untuk dibahas, sehingga sampai-sampai menanyakannya secara langsung kepada pemimpin mengenai siapa penggantinya. Padahal kondisi sang pemimpin tengah menghadapi sakit yang memayahkan fisiknya.

'Ali ibn Abī Tạlib meriwayatkan bahwa Nabi pernah ditanya:

Ya Rasulullah, siapakah yang patut diangkat menjadi pemimpin setelah engkau? Rasulullah menjawab, "Jika kalian mengangkat Abū Bakr, kalian akan mendapatkannya sebagai pemimpin yang jujur, zuhud dari kehidupan dunia dan condong kepada kehidupan akherat. Jika kalian mengangkat 'Umar, kalian akan mendapatkan seorang pemimpin yang kuat, jujur dan tidak takut sedikitpun akan celaan orang yang mencela di jalan Allah. Jika kalian mengangkat 'Ali, dan aku melihat kalian tidak akan melakukannya. Kalian akan mendapatkannya sebagai pemimpin yang mendapat petunjuk dan memberi petunjuk kepada kalian dan akan membawa kalian kepada jalan yang benar. ${ }^{34}$

Ini berarti bahwa wacana dan pemikiran tentang imämah muncul sejak zaman Rasulullah masih hidup dan puncak perselisihan itu pasca meninggalnya beliau. Sehingga muncul peristiwa yang terkenal dengan nama Thaqīfah banī Sa'̄īdah yang menyepakati Abū Bakr al-Ṣiddīq sebagai khalifah pertama. ${ }^{35}$ Terpilihnya Abū Bakr tidak membutuhkan waktu yang lama. Bahkan terbilang sangat cepat kalau dibandingkan dengan proses pemilihan pemimpin sepeninggalnya atau bakan pemilihan

${ }^{33} \mathrm{Ali}$ Ahmad as-Salus, Ensiklopedia Sunnah Syiah, Studi Perbandingan Akidah dan Tafsir, Jilid 1 (Jakarta: Pustaka Al-Kautsar, 2011), 27-8.

${ }^{34}$ Ibid.

35Umar Nahdi, Sejarah Umat Islam, Tsaqifah Bani Saidah, Jakarta: Obor, 1988), 36. 
pemimpin mana pun. Peristiwa Thaqifah menunjukkan betapa lapang dadanya kaum Anșār yang sebelumnya sudah menetapkan Sa'ad bin 'Ubādah sebagai pemimpin pengganti Rasulullah, namun mereka kemudian mau membaiat Abū Bakr sebagai khalifah.

Dukungan politik terhadap Sa'ad bin 'Ubādah untuk menggantikan kedudukan khalifah begitu besar, sebagaimana yang terjadi di Tsaqīfah. Namun ketundukan dan ketaatan terhadap perintah nabi begitu dijunjung tinggi. Peristiwa penting pengorbanan kaum Anșār dan kejelian kaum Muhajirin dalam menegakkan tonggak agama ini tercatat dalam tinta emas sejarah, sebagaimana perkataan 'Umar berikut:

"Ketika Rasulullah wafat, telah sampai berita bahwa kaum Anșār tidak berkumpul di kediaman Rasulullah. Namun mereka berkumpul untuk bersidang di Thaqīfah bani Sa'īdah. Sementara 'Alī dan Zubayr serta beberapa orang dari kalangan Muhajirin berkerumun menuju Abū Bakr." Maka 'Umar ibn al-Khațtāb berkata kepada Abū Bakr: "Wahai Abū Bakr, marilah kita bersama-sama berangkat menjumpai saudarasaudara kita dari kalangan Anșār " Lalu kami berangkat menuju mereka. Di tengah perjalanan, kami bertemu dengan dua orang saleh. Kedua orang itu menceritakan tentang kesepatan kaum Anșār untuk membaiat Sa'ad bin Ubadah sebagai khalifah, lantas kedua orang itu pun bertanya: "Ingin kemanakah kalian kaum Muhajirin ?" Kami menjawab: "Kami ingin bertemua saudara-saudara kami, kaum Anșār." Keduanya menyarankan kepada kami untuk tidak mendekati mereka dan memutuskan perkara kami di antara kami sendiri. maka Aku menjawab, "Demi Allah, kami akan tetap mendatangi mereka." Lalu kami berangkat hingga kita bertemu dengan mereka di Tsaqifah bani Sa'idah, sementara Sa'ad bin 'Ubadah sedang berselimut dan dalam keadaan sakit. Salah seorang kaum Anșār berpidato: "Kami adalah pembela dan penolong agama Allah serta tentara-tentara pembela agama Islam, sedangkan kalian wahai kaum Muhajirin adalah komunitas kecil dibandingkan kaum Anșār yang datang bersama-sama kerabat kalian dari Mekkah. Mereka bermaksud menjegal kami, dan menyingkirkan kami dari perkara ini." Setelah sambutan itu, maka aku ('Umar) ingin berbicara dengan kata-kata yang sudah dipersiapkan untuk mempresentasikannya di hadapan Abū Bakr, sedangkan posisiku berada di belakang Abū Bakr beberapa langkah. Ketika aku mau berbicara, Abū Bakr menegur dan berbicara,"Demi Allah, kebaikan atau peranan yang telah kalian uraikan memang tepat dan sesuai bagi kalian, dan perkara khilafah belum pernah dipimpin oleh golongan lain kecuali dari golongan Quraisy, karena mereka adalah bangsa Arab yang memiliki kemuliaan dan keturunan yang baik. Saya merestui salah satu di antara 
dua orang ini untuk dijadikan pemimpin kalian. Oleh karena itu pilihlah salah satunya yang kalian inginkan. Abū Bakr memegang tanganku dan Abū 'Ubaidah al-Jarrah." Kemudian Umar mengatakan,’Demi Allah, jika aku maju lalu leherku dipenggal sehingga tidak mendekatkan diriku kepada perbuatan dosa, itu lebih aku cintai daripada menjadi pemimpin sementara Abū Bakr ada di antara orang yang aku pimpin." Lalu seorang dari Anshar bersuara,"Saya tunas pohon yang kokoh, tempat berlindung dan penyangga, dari kami mengangkat seorang pemimpin, dan dari kalian wahai orang-orang Quraish diangkat seorang pemimpin juga." Akibat dari suara ini terjadi kebisingan sehingga dikhawatirkan akan terjadi peristiwa yang tidak diinginkan. Lalu aku berkata,"Bentangkan tanganmu ya Abū Bakr." Maka diulurkanlah tangannya, dan aku membaiatnya yang diikuti oleh kaum Muhajirin dan golongan Anshar pun sama- sama mengikuti kami. ${ }^{36}$

Peristiwa yang diceritakan di atas menunjukkan betapa besar pengorbanan kaum Anșar dan kekokohannya dalam memegang risalah kenabian dengan memegang teguh perintah Nabi tentang kedudukan orang Quraysh yang memiliki kemuliaan dan keturunan yang baik, sehingga mereka berbesar hati membaiat Abū Bakr sebagai khalifah dengan mengesampingkan Sa'ad bin 'Ubadah yang sudah mereka sepakati sebelumnya.

\section{Pandangan tentang Khilafah}

Sunni memandang bahwa kekhalifahan dalam Islam secara berurutan, dan diakui para ulama, adalah Abū Bakr al-Shiddiq, 'Umar ibn al-Khaț̣āb, Uthman bin 'Affān, dan 'Ali ibn Abī Tāalib. Sunni memandang kekhalifahan Abū Bakr secara aklamasi diakui oleh kaum muslimin baik dari kalangan Muhajirin maupun Anșar. Sebuah cerita yang masyhur dikatakan bahwa 'Ali ibn Abī Ṭālib tidak membaiat secara langsung sebagaimana umumnya kaum muslimin tetapi beberapa saat sesudahnya.

Diriwayatkan oleh Imām al-Bukhārī bahwa ketika 'Ali hendak membaiat Abū Bakr, 'Ali memohon waktu kepada Abū Bakr untuk menemuinya. Setelah mengucapkan kalimat syahadat, 'Ali berkata:

"Kami telah mengetahui keutamaan dan kelebihanmu dan apa yang telah Allah anugerahkan kepadamu. kami tidak iri hati (dengki) terhadap kedudukanmu sebagai khalifah, tetapi (amat disayangkan) anda tidak

36Ibid., 30-2. 
bermusyawarah dengan kami mengenai masalah ini karena kedekatan kami dengan Rasulullah membuat kami beranggapan bahwa kami mempunyai hak dalam masalah ini." Ucapan 'Ali membuat Abū Bakr meneteskan air mata. Pada saat Abū Bakr menyampaikan kata sambutannya mengatakan, "Demi Dzat diriku yang berada di dalam kekuasaan-Nya, sesungguhnya kerabat keluarga Rasulullah lebih saya utamakan dalam menjalin hubungan silaturrahim daripada dengan kerabat-kerabatku. Adapun perselisihan yang terjadi antara aku dan kamu adalah disebabkan harta. Aku tidak bermaksud menahan harta itu, namun aku tidak akan pernah meninggalkan suatu perkara yang pernah Rasulullah kerjakan." "Ali berkata kepada Abū Bakr, "Waktu untuk membaiatmu akan dilaksanakan setelah tergelincirnya matahari." Setelah Abū Bakr selesai mengerjakan salat zuhur, dia naik mimbar. Setelah mengucapkan syahadat dan shalawat, ia menyebutkan kedudukan 'Ali dan keterlambatannya di dalam pembaiatan serta kendala yang menghalanginya kemudian ia meminta maaf. Lalu 'Ali naik ke mimbar. Setelah mengucapkan syahadat, salawat, dan istigfar, 'Ali menyebutkan hak dan keutamaan pribadi Abū Bakr. Tetapi, kata 'Ali, kami berpandangan bahwa kami memiliki hak, sedangkan anda tidak bermusyawarah dengan kami. Maka orang-orang yang hadir bergembira dengan sikap 'Ali itu seraya berkata, "Engkau benar," sehingga ketika 'Ali mengoreksi permasalahan ini secara baik-baik, hal ini membuat kaum muslimin bertambah cinta dan dekat kepadanya. Kemudian 'Ali menyebutkan kemuliaan Abū Bakr dan keutamaannya, yaitu orang yang pertama beriman, lalu 'Ali berjalan menuju Abū Bakr untuk membaiatnya sedangkan kaum muslimin menyambutnya sambil berkata, "Engkau benar dan baik." 37

Sebelum masa kekhalifahannya berakhir, Abū Bakr berinisiatif untuk menunjuk 'Umar sebagai penggantinya. Hal itu diungkapkan di hadapan para sahabat yang mulai, namun mereka ada yang mengkhawatirkan karakter 'Umar yang dikenal memiliki temperamen yang keras, tegas, dan pemberani. Kekhawatiran itu dipatahkan oleh Abū Bakr dengan jawaban yang sangat argumentatif, "Jika Tuhanku menanyakan kepadaku pada hari Kiamat, pasti akan aku katakan, Aku telah mengangkat untuk mereka seorang yang terbaik dari hamba-Nya."

Atas usulan Abū Bakr itu, para sahabat merespon dengan berkata, "kami mendengar dan kami taat, dan hanya 'Ali ibn Abī Ṭālib yang mengatakan, "Kami tidak menganggap sah atau

${ }^{37}$ Ibn Hajar al-Asqalani, Fathul Bāri, kitab Jihād, Bab Rasūlullah: Kami tidak mewariskan berupa dunia, Apa yang aku tinggalkan menjadi shadaqah. 
mendukung selain Umar bin Khațtab. Tidak satupun sahabat yang terlambat ketika berlangsungnya pembaiatan Umar kecuali Sa'ad bin Ubādah. ${ }^{38}$

\section{Pentingnya Berpegang Tegub terhadap Ajaran dan Keluarga Nabi}

Sunni memandang bahwa sebelum meninggal, Nabi memerintahkan untuk berpegang teguh pada al-Qur'an dan Sunnah, serta perintah untuk memerhatikan keluarga beliau. Wasiat Nabi itu menunjukkan agar umat Islam menghormati dan mencintai keluarga Nabi dan memosisikan mereka pada posisi yang layak.

Ada hadis yang menunjukkan pentingnya memerhatikan keluarga Nabi, yakni dari Atiyah bin Abi Sa'id bahwa Nabi bersabda:

Aku telah tinggalkan bagi kalian dua perkara yang berharga. Satu di antara keduanya lebih besar dari yang lain, Kitabullah sebagai tali yang terulur dari langit ke bumi dan sanak keluarga dekatku. Keduanya tidak akan terpisah sampai keduanya menemuiku di al-haud (telaga di surga). ${ }^{39}$

Sesungguhnya aku telah meninggalkan kepada kalian dua khalifah, Kitabullah yang terulur antara langit dan bumi sesungguhnya keduanya tidak akan terpisah sampai keduanya (antara langit dan bumi) dan keturunan sanak keluargaku, dan sesungguhnya keduanya tidak akan terpisah sampai keduanya menemuiku di dalam al-band..$^{40}$

Dari paparan itu, semua hadis itu menunjukkan berita yang jelas dan tidak ada teks yang menunjukkan kepemimpinan harus dari keluarga Nabi; Nabi hanya berpesan untuk berpegang pada Kitabullah dan memerhatikan keturunan dan keluarga Nabi yang berpegang teguh pada ajaran Nabi itu. Sementara yang muncul justru kelompok Syiah yang mengaku-ngaku pembela abl al-bayt, padahal tujuannya adalah untuk kepentingan dunia, misalnya mengambil seperlima dari harta rampasan perang. Tidak hanya itu, mereka mengklaim diri mereka yang paling benar dan menganggap kelompok lain sesat, bahkan sampai pada tingkat saling mengkafirkan. ${ }^{41}$

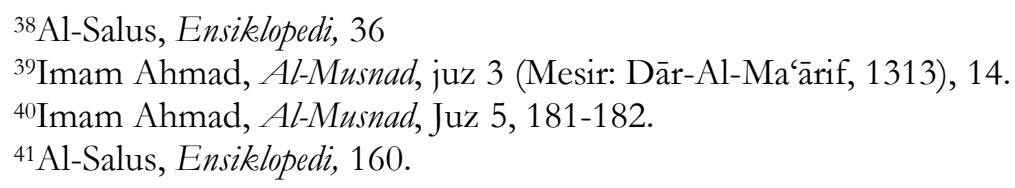




\section{Pemaknaan Abl al-Bayt}

Al-Salus mengutip pandangan Imām Al-Hākim, berkata bahwa yang dimaksud sanak keturunan Rasulullah adalah para 'ulamā' al-'ámilūn (para ulama yang giat bekerja), dimana mereka tidak pernah berpisah dengan al-Qur'an. Adapun mereka yang bodoh atau yang pintar tapi pemahamannya bercampur kebatilan, maka mereka berada di luar pusaran abl al-bayt. Sebaliknya apabila suatu kelompok berilmu, berakhlak dan berpegang pada al-Qur'an dan berpegang teguh pada ajaran Nabi sementara dia bukan dari keluarga dan keturunan Nabi, maka mereka perlu diikuti. ${ }^{42}$

Menurut Ibn Taymiyah, ijma' umat menjadi landasan hukum bersama al-Qur'an, dan Sunnah. Sanak keluarga Rasulullah adalah bagian dari umat dalam melakukan ijma'. Maka ijma' umat sama dengan ijma' sanak keluarga Rasulullah. ${ }^{43}$ Dengan demikian abl al-bayt adalah sanak keluarga Nabi yang berpegang teguh pada ajaran nabi dan menegakkan al-Qur'an dan Sunnah. Sementara yang berseberangan dengan keduanya, maka tidak pantas untuk disebut sebagai abl al-bayt. ${ }^{44}$

Syiah mengkategorikan abl al-bayt hanya pada keluarga 'Ali karena menikah dengan Fațimah, dengan asumsi Fațimah adalah putri nabi. Tetapi, ada saat yang sama, mereka tidak memasukkan 'Uthmān bin 'Affān padahal dua putri Nabi dinikahi olehnya. ${ }^{45}$ Utsman tidak hanya menikahi satu, tetapi dua putri, sehingga dia dijuluki Dzū al-Nurayn, yaitu Ruqayyah (yang meninggal tiga hari setelah perang Badar) dan bungsu Rasulullah yakni Ummu Kulthum. 'Uthmān dikeluarkan Syiah dari abl albayt karena membaiat Abū Bakr dan 'Umar serta menjadi khalifah setelah kedua khalifah itu meninggal, sehingga kitabkitab Syiah mengkafirkan dan memunafikkan 'Uthmān bin 'Affān itu. ${ }^{46}$

42Ibid., 162.

43Ibn Taymiyah, Minhāj al-Sunnah al-Nabawiyyah (Makkah: Jāmi'ah Imām Muhammad ibn Su'ūd, 1406)

${ }^{44} \mathrm{Al}-\mathrm{S}$ alus, Ensikelopedi, 163.

${ }^{45}$ Muhibbuddin al-Khathib, Dzu al-Nurayn 'Uthmän bin 'Affān $(1394 \mathrm{H})$.

${ }^{46} \mathrm{Al}-\mathrm{Salus}$, Ensiklopedi, 214. 
Sementara 'Umar bin Khattāa juga tidak dimasukkan Syiah sebagai abl al-bayt, mengapa? Padahal 'Ali ibn Abī Ṭālib itu menikahkan putrinya dengan khalifah kedua itu, dan hal itu semakin memperbagus dan memadukan dua pembesar sahabat itu. Tetapi Syiah mengatakan bahwa 'Ali menikahkan putrinya kepada 'Umar karena takut ancamannya. ${ }^{47}$

Tuduhan Syiah yang mengatakan 'Ali menikahkan karena ancaman 'Umar, bukan hanya mendiskreditkan Umar, namun hal itu merendahkan 'Ali sebagai orang yang dinilai kehilangan keberanian yang merupakan sifatnya yang sangat terkenal. Hal itu menempatkan 'Ali sebagai orang yang nista dan penakut.

Untuk memperkuat bahwa 'Ali mencintai tiga khalifah disebutkan dalam kitab Syiah Rafidhah, Mujam Rijäl al-Hadith karya Sayyid Abu al-Qasim al-Khaui, yang menyebutkan bahwa Imam 'Ali memilih tiga nama yang menjadi khalifah sebelumnya untuk semua putra dan cucunya. Di antaranya, putra 'Ali ada yang diberi nama $A b \bar{u}$ Bakr dan ada pula yang diberi nama 'Uthmān, dimana kedua putra 'Ali ini meninggal bersama saudaranya, Husain, di perang al-Tahuf. Cucu Imam 'Ali ada yang diberi nama Umar, yaitu putra Husain yang meninggal bersama bapaknya. Kedua putra Hasan diberi nama Abū Bakr dan 'Umar, yang meninggal bersama pamannya, Husain. 48

\section{Perbandingan Pandangan Syiah-Sunni}

\section{Perdebatan Imamah}

Imämah merupakan aspek yang menjadi perdebatan antara Sunni dan Syiah, sehingga menjadikan dua aliran ini tidak bisa bertemu baik dalam pemikiran keagamaan maupun perilaku ritual keagamaan.

Syiah memiliki keyakinan dasar yang membedakannya dengan ajaran-ajaran Sunni. Pertama, imāmah (kepemimpinan), bahwa seorang umat Islam harus percaya terhadap hal tersebut, dan kepemimpinan itu dipimpin oleh imam yang ma'șüm.

\footnotetext{
${ }^{47}$ Syaikh Muhammad Hasan al-'Amili, Wasāill al-Shīah ilā Tashīl Masāìl al-Shar'̄ah, jilid 14 (Kairo: Maṭbu’āt al-Najāh, 1391 H) 433-4.

${ }^{48}$ Sayyid Abu al-Qasim al-Musawa al-Khaui, Mujam Rijäl al-Hadith, (Najf, 1390 H/1970 M).
} 
Seseorang tanpa adanya kepemimpinan seorang yang ma'süm maka akan lemah. Kedua, bada' (mengetahui hal yang gaib). Bahwa seorang imam mengetahui hal-hal yang telah dan akan terjadi. Ketiga, raj'ah (reinkarnasi), seorang imam akan muncul kembali untuk memperbaiki kondisi umat yang sudah rusak. Keempat, taqiyyah (kepura-puraan). Seseorang bisa menampilkan kepercayaan dan perilaku yang lain dalam rangka menjaga keimanannya.

Dalam pandangan Syiah 'Ashariyah bahwa seorang imam wajib ma'șum, sehingga ada kepastian bagi orang-orang mukallaf. Imam adalah bujjah Allah dan perkataannya adalah firman Allah, sedangkan perkataan Rasulullah dan hukumnya wajib ditaati dan diterima dengan sepenuh hati serta mengembalikan masalah kepadanya dengan yakin dan pasti. ${ }^{49}$

Dalam pandangan Sunni, bahwa kepemimpinan (imämah) bukan merupakan hal yang menjadi rukun, namun kalangan Syiah membelokkan dan mengada-ada masalah kepemimpinan tersebut dengan merujuk pada sejarah Gadir Khum. Sunni berpandangan bahwa peristiwa Gadir Khum merupakan catatan yang amat bersejarah. Di tempat itu, setelah melakukan haji Wada, Rasulullah mewasiatkan berbagai pesan yang amat berharga, di antaranya tentang kehormatan dan kemuliaan harta, darah dan jiwa kaum muslimin; kewajiban sebagai seorang hamba dengan yang lain dan kewajiban suami istri. Dalam momentum yang penting itu Rasulullah ingin menunjukkan bahwa kesempurnaan Islam betul-betul fakta dan bahwa risalah kenabian betul-betul tuntas dan disaksikan umat Islam.

Kalangan Syiah, khususnya Syiah Ja'fariyah berkeyakinan bahwa di dalam khutbah Gadir Rasulullah tersebut terdapat perintah kepada umatnya untuk berpegang teguh kepada alQur'an dan sanak keturunannya karena sesungguhnya beliau telah meninggalkan dua peninggalan yang amat berarti, yakni alQur'an dan sanak keluarganya. Sementara bagi kalangan Sunni, berpegang teguh pada Kitabullah dan Sunnahnya dalam arti sunnah yang terdapat dalam sepuluh kitab yakni Șahị Bukhāri, Șahị Muslīm, Musnad Aḥmad, Musnad al-Tirmīdzi, Musnad alNasā’i dan Musnad Ibn Mājah.

${ }^{49} \mathrm{Al}-$ Salus, Ensiklopedi, 361. 


\section{Dalam Șaḥị̣ Bukhāri disebutkan, bahwa:}

Para imam sesudah Nabi meminta nasehat kepada orang-orang yang dipercaya dari para ulama dalam perkara yang mubah untuk memilih yang paling mudah dikerjakan, maka apabila al-Qur'an dan Sunnah telah menjelaskannya, suapaya tidak mengambil pendapat dari yang lain sebagai tanda mengikuti Nabi. ${ }^{50}$

\section{Imām Bukhāri meriwayatkan dari 'Ubaidillāh bin 'Abdullāh} dari Ibn 'Abbās berkata:

"Saat Nabi datang, di dalam rumah ada beberapa sahabat, di antaranya Umar bin Khaththab, lalu beliau bersabda, kemarilah kalian, aku akan menuliskan buat kalian sebuah kitab dimana kalian tidak akan sesat sesudahnya." Umar berkata, "Sesungguhnya Nabi sudah tidak tahan merasakan sakit, dan kalian telah memiliki al-Qur'an, maka cukuplah bagi kami Kitabullah (al-Qur'an)." Kemudian orang-orang berselisih dan bertengkar. Di antara mereka ada yang berkata,"Mendekatlah kalian ! karena Rasulullah akan menuliskan buat kalian satu kitab dimana kalian tidak akan sesat sesudahnya." Juga ada lagi di antara mereka yang berkata seperti yang telah dikatakan. Maka saat mereka gaduh dan tidak karuan, Nabi bersabda, "Pergilah kalian dariku !"51

Sa īid bin Jubair dari Ibn Abbās bahwa Rasulullah bersabda:

"Biarkan aku, sesungguhnya tempat dimana aku berada lebih baik daripada yang mereka ajak untuk datang kepadanya". Lalu Rasulullah memberikan tiga wasiat, "Keluarkanlah orang-orang musyrik dari Jazirah Arab, ambillah jizyah dari orang asing (non-muslim) sebesar apa yang pernah aku ambil dari mereka." Kemudian beliau terdiam tentang wasiat ketiga atau beliau berkata, "Aku lupa yang ketiga." 52

Kalangan Syiah berkeyakinan bahwa wasiat Nabi yang ketiga adalah agar mengangkat 'Ali sebagai pemimpin mereka. Bahkan Kalangan Syiah Ja'fariyah ada yang mengatakan bahwa "AlFaruq ('Umar ibn Khațab) mengakui bahwa yang dimaksud dengan al-Kitab adalah konsolidasi wasiat kekhalifahan Ali dan para imam dari keturunannya, kemudia dia ('Umar) bersama para pembesar sahabat telah mencegah Rasulullah untuk melakukan hal itu." 53

\footnotetext{
${ }^{50}$ Bukhāri, Al-I'tisham bi al-Kitab wa al-Sunnah.

${ }^{51}$ Ibid.

${ }^{52 B u k h a ̄ r i, ~ S a h i ̣ h ~ B u k h a ̄ r i, ~ B a b ~ S a k i t n y a ~ N a b i ~ d a n ~ w a f a t n y a . ~}$

${ }^{53}$ Ingenity of Umar, 209-210, dikutip oleh Ali Ahmad As-Salus
} 
Dalam kitab al-Muwaț̣a', Imam Malik menyebutkan sabda Nabi, "Telah aku tinggalkan bagi kalian dua perkara dan kalian tidak akan sesat selama kalian berpegang keduanya, Kitabullah dan Sunnah nabi-Nya." 54

Syiah menganggap bahwa peristiwa di Gadir Khum merupakan momentum wasiat Nabi kepada Ali untuk menggantikannya setelah Nabi meninggal. Sementara bagi Sunni, bahwa Gadir Khum merupakan penegasan Rasulullah untuk berpegang pada Kitabullah dan Sunnah Nabi, serta penegasan Nabi untuk memperhatikan sanak keluarga yang merupakan pewaris agama Nabi.

\section{Pandangan tentang Al-Qur'an}

Perdebatan yang tidak pernah selesai dari Syiah dan Sunni adalah masalah keotentikan al-Qur'an. Syiah mempercayai bahwa al-Qur'an yang kita pegang saat ini adalah berbeda dengan saat diturunkan kepada Rasulullah, namun jumhur ulama Sunni berpandangan bahwa al-Qur'an yang dipegang oleh kaum muslimin, atau disebut sebagai muṣhaf 'Uthmāni merupakan hasil karya para sahabat yang mulia dan terjaga hingga hari kiamat. Sebagaimana Firman Allah: "Tidak ada perubahan bagi kalimat-kalimat Allah. yang demikian itu adalah kemenangan yang besar". (Qs. Yunus [10]: 64). "Sesungguhnya Kami-lah yang menurunkan al-Quran, dan Sesungguhnya Kami benarbenar memeliharanya". (Qs. al-Hijr [15]: 9).

Dalam pandangan Sunni bahwa keterangan ini memberikan jaminan tentang kesucian dan kemurnian al-Qur'an selamalamanya dengan mempersiapkan orang-orang yang menjaganya dengan menghafal dan mengajarkan kepada orang lain. Sunni berkeyakinan bahwa al-Qur'an telah ditulis di zaman Rasulullah dan dihimpun pada zaman Abū Bakr al-Ṣiddīq kemudian di zaman 'Umar ibn Khațtāb kemudian ditulis pada zaman 'Utsmān ibn 'Affān yang kemudian dikenal dengan Muṣhaf 'Utsmāni, yang telah terjaga di dada kaum muslimin sepanjang masa. ${ }^{55}$

54Imām Mālik, Al-Muwațta', Juz I, 6.

${ }^{55} \mathrm{Al}-\mathrm{Salus,}$ Ensiklopedi, 571. 
Kalangan Syiah, khususnya Syiah Ithna 'Ashariyah merasa kegerahan dengan kesepakatan jumhur Ahl al-Sunnah tentang keabsahan al-Qur'an terhadap muṣhaf Uthmāni itu. Kelompok ekstrem Syiah mencemooh para sahabat yang mulia khususnya Abū Bakr, 'Umar dan 'Utsmān, yang dianggap tidak amanah dalam menerapkan syariat Islam serta dalam penjagaan kitab Allah ini. Tiga khalifah itu dianggap merampas khilafah dari tangan 'Ali, dan melakukan perubahan terhadap al-Qur'an agar tindakan-tindakan mereka tidak terbongkar dan tidak tampak hak Ali dan para imam sesudahnya dalam khilafah. ${ }^{56}$

Sebagian dari kalangan Syiah ada yang menulis bahwa Utsman bin 'Affān telah membakar seluruh mushaf, serta menghapus surat-surat yang di dalamnya menyebutkan keutamaan 'Ali dan abl al-baytnya. Namun dalam kelompok Syiah juga ada yang berpandangan sebagaimana umumnya ulama Sunni bahwa al-Qur'an tidak mengalami perubahan sebagaimana yang diyakini Syiah Ja'fariyah. Salah satu perkataan Sayyid alMurtaḍa bahwa al-Qur'an merupakan mukjizat, sumber pengambilan hukum syariah dan hukum-hukum agama. Mereka berdalil bahwa Ulama telah menjaga dan menghafalnya dengan sangat serius hingga mereka tahu segala perbedaan yang ada di dalamnya dari sudut i'rabnya, bacaan (qira'at) dan huruf-huruf serta ayat-ayatnya. Lalu bagaimana mungkin ia telah berubah dan berkurang padahal penjagaan kaum muslimin demikian serius, jujur dan penuh dengan kehati-hatian. Intinya adalah al-Qur'an yang dihimpun pada masa Rasulullah sama seperti apa yang ada di tangan umat Islam sekarang.

Syaikh al-Ṭusi juga mengatakan bahwa pendapat yang mengatakan bahwa di dalam al-Qur'an ada tambahan dan pengurangan, merupakan pendapat yang tidak pantas untuk diungkapkan. Karena perkataan bahwa di dalam al-Qur'an ada tambahan telah disepakati sebagai sesuatu yang batil, begitu pula yang mengatakan bahwa al-Qur'an mengalami pengurangan. Karena al-Qur'an yang ada di tangan kita sudah diketahui kesahihannya, dimana tidak ada yang menentang dan tidak ada pula yang menolak. ${ }^{57}$ Namun pandangan ini tertutupi dengan

\footnotetext{
${ }^{56} \mathrm{Al}$-Salus, Ensiklopedi, 571.

${ }^{57}$ Al-Ṭusi, Al-Tibyän, Juz I, 3.
} 
pemahaman yang umum dipercayai kalangan Syiah yang percaya bahwa al-Qur'an telah mengalami perubahan, dan tidak otentik lagi sebagaimana ketika diturunkan pada Rasulullah.

\section{Pandangan tentang Khilafab Abu Bakr}

Dalam pandangan Syiah, kepemimpinan Abū Bakr dianggap tidak sah karena dianggap merampas kekhilafahan Ali yang telah mendapat mandat langsung dari Rasulullah. Al-Haytami menulis buku tentang Abū Bakr, sebagai bukti otentik tentang keutamaan Abū Bakr secara terperinci dengan berbagai dalil yang kuat. ${ }^{58}$ Buku itu memuat beberapa hal, sebagaimana dipaparkan di bawah ini:

Pertama, para sahabat Anșar yang sudah menetapkan Sa'ad bin 'Ubādah, namun mencabut ketetapan itu dengan membaiat Abū Bakr setelah datangnya berita tentang perintah Rasulullah kepada Abū Bakr untuk mengimami manusia dalam shalat ? Mereka menjawab, "Kami berlindung kepada Allah jika kami mendahului Abū Bakr." 59 Keterangan ini menunjukkan bahwa sahabat Anșar secara de fakto sangat pantas untuk memilih pemimpin dari kalangan mereka, padahal Madinah adalah tanah mereka, jumlah mereka lebih banyak, dan bukti pengorbanan mereka telah nyata membantu dan menerima para sahabat dari Muhajirin, namun mereka begitu taat terhadap perintah dan ketetapan Rasulullah yang mengisyaratkan Abū Bakr sebagai khalifah.

Kedua, Abdurrahman bin 'Auf menyaksikan khutbah Abū Bakr saat dilantik jadi khalifah, "Demi Allah, Aku tidak pernah menginginkan khilafah sama sekali baik siang maupun malam. Aku juga tidak menyenanginya dan tidak pernah memintanya kepada Allah dalam waktu sunyi maupun keramaian. Tetapi aku mengkhawatirkan terjadinya fitnah, dan aku tidak merasa sedikitpun terhadap khilafah." Keterangan ini menunjukkan bahwa sosok Abū Bakr bukanlah sosok yang ambisius terhadap khilafah, dan bahkan tidak ada pikiran untuk mendudukinya karena takut adanya fitnah ketika memegang kekuasaan.

Ketiga, semua sahabat berkonsesus atas khilafah Abū Bakr, maka demikian itu tidak dapat dijadikan dasar tentang tidak berhaknya Abū Bakr atas khilafah. Terlebih 'Ali ibn Abī Țālib termasuk orang yang menceritakan adanya konsensus atas hal tersebut. Sebagaimana dikatakan Imam Baihaqi menyebutkan riwayat dari al-Za'rafani, ia berkata, "Saya mendengar Imam Shāfíi berkata,"Kaum muslimin

58 Aḥmad bin Hajar al-Haitami al-Makki, Al-Sawāiq al-Mubriqah fi alRaddi' 'alà Abli al-Bida' wa al-Zandaqah,

${ }^{59} \mathrm{Ibid}, 21$. 
bersepakat atas kekhalifahan Abū Bakr. Karena pada saat itu mereka bergejolak pasca meninggalnya Rasulullah, namun mereka tidak mendapatkan di kolong langit ini orang yang lebih baik daripada Abū Bakr maka mereka menyerahkan urusan mereka kepadanya." Para sahabat tidak meragukan bahwa Abū Bakr adalah khalifah Rasulullah, Sesungguhnya dialah orang yang mendampingi Rasulullah ketika dalam gua, dan kami mengetahui kemuliaan dan keseniorannya."

Al-Haytami mengutip al-Qur'an untuk menjelaskan kedudukan Abū Bakr sebagai representasi dari manusia terbaik. Ayat itu berbunyi:

Hai orang-orang yang beriman, Barangsiapa di antara kamu yang murtad dari agamanya, Maka kelak Allah akan mendatangkan suatu kaum yang Allah mencintai mereka dan merekapun mencintai-Nya, yang bersikap lemah lembut terhadap orang yang mukmin, yang bersikap keras terhadap orang-orang kafir, yang berjihad di jalan Allah, dan yang tidak takut kepada celaan orang yang suka mencela. Itulah karunia Allah, diberikan-Nya kepada siapa yang dikehendaki-Nya, dan Allah Maha Luas (pemberian-Nya), lagi Maha Mengetahui. (Qs. alMaidah [5]: 54)

Al-Bayhaqi menyebutkan riwayat Hasan al-Bașri yang berkata, "Demi Allah, ketika orang-orang Arab murtad, maka Abū Bakr dan sahabat-sahabatnya berjihad memerangi mereka sehingga mengembalikan mereka kepada Islam." Peran Abū Bakr sebagai khlaifah begitu besar untuk memerangi kaum yang murtad terhadap Islam karena menolak membayar zakat yang sudah berjalan ketika Rasulullah masih hidup.

Banyak hadis yang menyebutkan keutamaan Abū Bakr yang diucapkan secara langsung oleh Rasulullah, di antaranya:

"Sesungguhnya aku tidak mengerti apa yang ditakdirkan Allah tentang sisa usiaku bersama kamu, maka ikutilah dua orang setelahku, Abū Bakr dan 'Umar. Berpegang teguhlah kepada bimbingan Ammar, dan benarkanlah hadis yang disampaikan Ibn Mas'ūd." (HR. Imām Aḥmad, al-Tỉrmīdhi, Ibn Mājah dan Ibn Hibbān).

Rasulullah kepada manusia bersabda: "Sesungguhnya Allah memberikan pilihan kepada seorang hamba antara dunia dan apa yang di sisi-Nya, lalu hamba itu memilih apa yang di sisi Allah." Maka Abū Bakr menangis dan berkata: "Kami utamakan kamu atas ibu dan bapak kami." Kami heran atas menangisnya Abū Bakr, karena Rasulullah memberitahukan seseorang hamba yang diberikan pilihan oleh Allah. Sebab Rasulullah adalah hamba yang diberikan pilihan, dan Abū Bakr adalah orang yang paling mengetahui di antara kami. Lalu Rasulullah 
bersabda: "Sesungguhnya manusia yang paling memberi kepadaku dalam persahabatan dan hartanya adalah Abū Bakr. Dan jika aku menjadikan kekasih selain Tuhanku niscaya aku jadikan Abū Bakr sebagai kekasih dalam persaudaraan dan cinta kasih dalam Islam. Tidak tersisa satu pintu pun yang ditutup kecuali pintu Abū Bakr". (HR. Imām al-Bukhāri dan Imām Muslim)

Bani Musțaliq mengutusku kepada Rasulullah untuk bertanya: "Kepada siapa kami menyerahkan zakat setelahmu? Lalu aku datang kepadanya dan bertanya, maka beliau berkata: "kepada Abū Bakr." (HR. Imām alḤākim)

Kata A'īshah, Rasulullah berkata kepadaku pada waktu sakit yang kemudian beliau meninggal karena sakitnya itu. "Panggillah bapakmu dan saudaramu untuk menghadap kepadaku sehingga aku menuliskan suatu tulisan. Sebab aku sangat mengkhawatirkan bila seseorang berharap dan mengatakan bahwa dia lebih berhak (atas khilafah). Namun Allah dan orang-orang mukmin hanya memilih Abū Bakr." (HR. Imām al-Hāākim)

Dari Abū Mūsa al-Asy'āri, bahwa ketika Nabi sakit lalu semakin keras sakitnya, maka beliau berkata,"Perintahkanlah Abū Bakr shalat bersama manusia." A'ishah berkata,"Wahai Rasulullah, sesungguhnya dia orang yang sangat sensitif. Jika dia berdiri bersamamu maka dia tidak akan mampu salat dengan orang-orang." Maka Nabi bersabda: "Perintahkanlah Abū Bakr untuk salat dengan orang-orang," lalu A 'īshah mengulangi pernyataannya tersebut. Maka Nabi bersabda: "Perintahkan Abū Bakr untuk salat dengan orang-orang. Sesungguhnya kamu seperti wanita-wanita pada masa Nabi Yusuf." Lalu Nabi menemui Abū Bakr. Maka Abū Bakr salat mengimami orang-orang pada masa hidup Rasulullah. (HR. Imām al-Bukhāri dan Imām Muslim)

Ketika Rasulullah membangun masjid dan telah meletakkan batu dalam bangunan, maka beliau berkata kepada Abū Bakr, "Letakkanlah batumu di samping batuku." Kemudian berkata kepada "Umar, "Letakkanlah batumu di samping batu Abū Bakr." Kemudian berkata kepada 'Uthmān, "Letakkanlah batumu di samping batu 'Umar." Kemudian beliau berkata, "Mereka adalah para khalifah sesudahku". (HR. Ibn Hibban)

Dari paparan di atas menunjukkan bahwa Abū Bakr di mata Sunni merupakan sosok yang berhak atas khilafah karena memiliki sejumlah keutamaan dan kemuliaan yang tidak dimiliki oleh manusia seluruh ciptaan Allah sesudah para Nabi dan para Rasul. Hal itu sekaligus membedakan dari cara pandang Syiah yang menilai Abū Bakr sebagai manusia hina, berhala Quraysh, karena dianggap merampas hak khilafah 'Alī ibn Abī Ṭālib. 


\section{Pemaknaan terbadap Abl al-Bayt}

Abl al-bayt merupakan entry point untuk melihat perbedaan Syiah dan Sunni. Al-Salus mengutip pandangan Imām al-Hākim yang mengatakan bahwa yang dimaksud sanak keturunan Rasulullah adalah para 'ulamà' al-'amilun (para ulama yang giat bekerja), dimana mereka tidak pernah berpisah dengan alQur'an. Adapun mereka yang bodoh atau yang pintar tapi pemahamannya bercampur kebatilan, maka mereka berada di luar pusaran abl al-bayt. Sebaliknya apabila suatu kelompok berilmu, berakhlak dan berpegang pada al-Qur'an dan berpegang teguh pada ajaran Nabi meskipun dia bukan dari keluarga dan keturunan Nabi, maka mereka perlu diikuti. ${ }^{60}$

Sementara menurut Ibn Taymiyah bahwa ijma' umat menjadi landasan hukum bersama al-Qur'an, Sunnah dan ijma'. Sementara sanak keluarga Rasulullah adalah bagian dari umat dalam melakukan ijma'. Maka ijma' umat sama dengan ijma' sanak keluarga Rasulullah. ${ }^{61}$

Dengan demikian abl al-bayt adalah sanak keluarga Nabi yang berpegang teguh pada ajaran Nabi dan menegakkan al-Qur'an dan sunnah. Sementara yang berseberangan dengan keduanya, maka tidak pantas untuk disebut sebagai abl al-bayt. ${ }^{62}$

Syiah mengategorikan abl al-bayt hanya pada keluarga Ali karena menikah dengan Fāṭimah, dengan asumsi Fāțimah adalah putri nabi, sementara pada saat yang sama, mereka tidak memasukkan 'Uthmān bin 'Affān walaupun dia menikahi dua putri Nabi. ${ }^{63}$ Alasan Syiah mengeluarkan Uthmān dari abl al-bayt karena membaiat Abū Bakr dan 'Umar serta menjadi khalifah setelah kedua khalifah itu meninggal. Kitab-kitab Syiah mengkafirkan dan memunafikkan 'Uthmān ibn 'Affān. ${ }^{64}$

Syiah juga tidak memasukkan 'Umar ibn Khaț̣āb sebagai abl al-bayt padahal 'Alī ibn Abī Ṭālib menikahkan putrinya dengan khalifah kedua itu. Syiah berpandangan bahwa 'Alī menikahkan

\footnotetext{
${ }^{60} \mathrm{Al}$-Salus, Ensiklopedi, 162.

${ }^{61} \mathrm{Ibn}$ Taymiyah, Minhäj, 43.

${ }^{62} \mathrm{Al}-\mathrm{S}$ alus, Ensiklopedi, 163.

${ }^{63} \mathrm{Al}-\mathrm{Khātib}$, Džu al-Nurayn.

${ }^{64} \mathrm{Al}-\mathrm{S}$ alus, Ensiklopedi, 214.
} 
putrinya kepada 'Umar karena takut ancamannya. ${ }^{65}$ Tuduhan Syiah yang mengatakan 'Ali menikahkan karena ancaman 'Umar, bukan hanya mendiskreditkan 'Umar, tetapi juga merendahkan 'Ali sebagai orang yang kehilangan keberanian yang merupakan sifatnya yang sangat terkenal. Hal itu menempatkan 'Ali sebagai orang yang nista dan penakut.

Begitu bencinya kepada ketiga khalifah itu, Syiah sampai menutupi kebaikan ketiganya, dan melebih-lebihkan sikap yang tidak pada tempatnya. Misalnya, ketika menjelaskan latar belakang turunnya Qs. al-Jumu'ah (62): 11 yang terjemahannya:

Dan apabila mereka melihat perniagaan atau permainan, mereka bubar untuk menuju kepadanya dan mereka tinggalkan kamu sedang berdiri (berkhutbah). Katakanlah: "Apa yang di sisi Allah lebih baik daripada permainan dan perniagaan, dan Allah sebaik-baik pemberi rezki".

Kalangan Syiah memandang, dengan merujuk pada ungkapan Abd al-Husayn al-Musawi, ketika Dahyah al-Kalbi yang datang pada hari Jum'at membawa bahan makanan dari Syam, maka para sahabat pergi dan meninggalkan Nabi yang saat itu sedang berkhutbah kecuali 'Alī, Hasan, Husayn, Fāṭimah, Salman, Abū Dhar, dan Miqdād ibn Aswad. ${ }^{66}$ Sementara ada keterangan lain yang dikatakan Jabir bin Abdillah, bahwa di dalam masjid itu ada dua belas orang termasuk saya, Abū Bakr dan 'Umar. ${ }^{67}$ Ibn Abbas mengatakan bahwa yang tersisa dalam masjid itu adalah empat khulafaurrasyidin, Ibn Mas'ud, dan beberapa orang dari sahabat Anșār."'68

Dengan demikian keberadaan Abū Bakr untuk tetap di masjid merupakan kebaikan yang ditutupi dengan membesarbesarkan keluarga Ali, sehingga objektivitas dalam memandang realitas yang sebenarnya menjadi sirna.

\section{Pandangan terbadap 'Ali ibn Abi Talib}

Kalau Syiah berkeyakinan bahwa imämah merupakan hal yang wajib, dan 'Alī ibn Abì Ṭālib merupakan figur yang pantas. Imāmah itu merupakan hak kelompok abl al-bayt yang terlepas ke

\footnotetext{
${ }^{65}$ Wasail , XIV, 433-4.

${ }^{66} \mathrm{Al}-\mathrm{S}$ alus, Ensikelopedi, 219.

${ }^{67}$ Al-Dur Al-Mansur, Jilid 4, 220-1.

68Ibn Hajar, Sahīh Muslim, Jilid 1, 214.
} 
tangan Abū Bakr dan 'Umar ibn al-Khațtāb serta berlanjut ke 'Uthmān ibn 'Affān. Di pihak lain, Sunni mengakui keutamaan 'Ali namun tetap menilai Abū Bakr merupakan figur yang lebih utama dan pantas dalam soal khilafah.

Syiah dan Sunni sepakat bahwa seorang nabi merupakan seorang pemimpin yang ma'süm, dan hanya beliaulah yang ditetapkan ke-ma'șüm-annya. Meskipun demikian, Syiah juga menerapkan kepada para imam mereka memiliki derajat seperti Nabi yang ma'śm. ${ }^{69}$ Dalam pandangan Sunni, ketaatan terhadap pemimpin yang selaras dan menghukumi dengan al-Qur'an dan Sunnah merupakan tolok ukur, bukan disandarkan pada kema'șum-an pemimpin. Sebagaimana Firman Allah dalam Qs. alNisā' (4): 59:

Hai orang-orang yang beriman, taatilah Allah dan taatilah Rasul (Nya), dan ulil amri di antara kamu. Kemudian jika kamu berlainan pendapat tentang sesuatu, maka kembalikanlah ia kepada Allah (al-Qur'an) dan Rasul (sunnah), jika kamu benar-benar beriman kepada Allah dan hari kemudian. Yang demikian itu lebih utama (bagimu) dan lebih baik akibatnya.

\section{Memaknai Fatwa MUI tentang Kesesatan Ajaran Syiah}

Bukti tidak bisa bersatunya Syiah dan Sunni adalah munculnya fatwa Majelis Ulama Indonesia (MUI) yang merespon kesesatan ajaran Syiah, khususnya di Jawa Timur. Merujuk berbagai laporan dari berbagai daerah, yang melaporkan sejumlah aliran yang dikategorikan menyimpang dari prinsipprinsip agama Islam maka muncul fatwa MUI itu. Adapun poinpoin penting fatwa MUI itu adalah: 70

Pertama, mengukuhkan dan menetapkan bahwa ajaran Syiah, khususnya Imamiyah Ithna 'Ash'ariyah dan/atau yang menggunakan nama samaran mazhab abl al-bayt dan semisalnya serta ajaran-ajaran yang mempunyai kesamaan dengannya adalah "sesat dan menyesatkan". Kedua, menyatakan bahwa penggunaan istilah abl al-bayt untuk pengikut Syiah adalah bentuk pembajakan kepada abl al-bayt Rasulullah.

${ }^{69} \mathrm{Al}-$ Salus, Ensiklopedi, 368.

${ }^{70}$ Ainul Yaqin (Peny.), Fatwa MUI Provinsi Jawa Timur tentang Kesesatan Ajaran Syiah (Surabaya: MUI Provinsi Jawa Timur, 2012). 
Ketiga, merekomendasikan: (a) kepada umat Islam diminta untuk waspada agar tidak mudah terpengaruh dengan faham dan ajaran Syiah (khususnya Imämiyah Ithna 'Ash'ariyah dan/atau yang menggunakan nama samaran madzab Ahl al-bayt dan semisalnya). (b) Kepada umat Islam diminta tidak mudah terprovokasi melakukan tindakan kekerasan (anarkisme) karena hal tersebut tidak dibenarkan dalam Islam serta bertolak belakang dengan upaya membina suasana kondusif untuk kelancaran dakwah Islam. (c) Kepada pemerintah baik pusat maupun daerah dimohon agar tidak memberikan peluang penyebaran faham Syiah di Indonesia, karena penyebaran faham Syiah di Indonesia yang penduduknya mayoritas berpaham $A b l$ al-Sunnah wa al-Jama'ah sangat berpeluang menimbulkan ketidakstabilan yang dapat mengancam keutuhan NKRI. (d) Kepada pemerintah baik pusat maupun daerah dimohon agar melakukan tindakan-tindakan sesuai dengan peraturan perundang-undangan yang berlaku antara lain membekukan/melarang aktivitas Syiah beserta lembaga-lembaga yang terkait. (e) Kepada pemerintah baik pusat maupun daerah dimohon agar bertindak tegas dalam menangani konflik yang terjadi, melihat masalah secara utuh dan keseluruhan tidak hanya melihat pada kejadiannya saja, tetapi juga faktor yang menjadi penyulut terjadinya konflik. Karena penyulut konflik adalah provokator yang telah melakukan teror dan kekerasan mental sehingga harus ada penanganan secara komprehensif. (f) Kepada pemerintah baik pusat maupun daerah dimohon agar bertindak tegas dalam menangani aliran menyimpang karena hal itu bukan termasuk kebebasan beragama tetapi penodaan agama.

Pada bagian penutup MUI Jawa Timur memohon kepada MUI pusat agar mengukuhkan fatwa tentang kesesatan Syiah (khususnya Imämiyah Ithna 'Ashariyah dan/atau yang menggunakan nama samaran madzab Abl al-Bayt dan semisalnya) serta ajaran-ajaran yang mempunyai kesamaan dengan faham Syiah sebagai fatwa yang berlaku secara nasional.

Kalau merujuk pada fatwa yang dikeluarkan oleh MUI Jawa Timur ini menunjukkan bahwa Syiah sebagai sebuah ajaran keagamaan tidak mungkin bisa hidup berdampingan dalam 
komunitas Sunni, apalagi penganut Sunni di Indonesia merupakan jumlah yang mayoritas.

\section{Catatan Akhir}

Syiah dan Sunni sama-sama mengakui Islam sebagai agama yang benar dan diturunkan Allah lewat Rasulullah dengan petunjuk yang termaktub dalam al-Qur'an. Al-Qur'an diyakini memberikan konsep kehidupan di dunia untuk keselamatan akhirat. Namun demikian, terdapat lima masalah yang menjadikan kedua aliran pemikiran keagamaan ini sulit untuk dipertemukan yakni masalah imämah, keotentikan al-Qur'an, khiläfah Abū Bakr, hak khilāfah atas 'Alī ibn Abī TTālib, dan pemaknaan terhadap abl al-bayt.

Syiah menempatkan imāmah sebagai rukun dan masuk dalam ranah akidah, dan seorang muslim harus mengimani, dan siapapun yang tidak mengakuinya bisa tergolong kafir. sementara Sunni mengakui imāmah dalam konteks bahwa umat Islam harus mengakui dan berpegang teguh terhadap ajaran Islam yang telah diajarkan oleh Rasulullah dan diamalkan para sahabat.

Syiah percaya bahwa al-Qur'an masih otentik, namun secara umum, Syiah meyakini bahwa al-Qur'an tidak otentik lagi dan tidak asli sebagaimana ketika diturunkan kepada Rasulullah. Dengan kata lain, al-Qur'an mengalami perubahan. Sementara Sunni mengakui bahwa al-Qur'an masih terjaga keasliannya sampai hari kiamat dengan jaminan Allah.

Syiah memandang bahwa Abū Bakr merupakan sahabat tidak sah karena merampas hak yang telah menjadi hak milik 'Ali ibn Abī Ṭālib sebagaimana yang terjadi di Ghadir Khum, sementara Sunni memandang khilafah Abū Bakr merupakan kepemimpinan yang sah dan absah baik menurut al-Qur'an maupun penegasan Rasulullah yang menunjukkan bahwa Abū Bakr merupakan representasi manusia terbaik di dunia dan di akhirat setelah para Nabi dan Rasul.

Syiah memandang bahwa suami Fāțimah atau menantu Rasulullah merupakan figur terbaik di antara para sahabat karena memiliki andil yang besar terhadap Islam, dan menerima wasiat langsung dari Rasulullah untuk mengemban khilafah sepeninggal 
Rasulullah, namun wasiat itu dirampas oleh khalifah Abū Bakr dan 'Umar sehingga khilafah itu tidak di tangannya.

Syiah memandang bahwa abl al-bayt adalah sanak keluarga Rasulullah dari jalur Fāṭimah yang bersuamikan 'Alī ibn Abī Tālib. Jalur itu berkelanjutan pada keturunan mereka berdua, sehingga melahirkan imam dua belas yang dianggap representasi para imam yang mewarisi nilai-nilai kenabian. Sementara Sunni memandang bahwa abl al-bayt tidak hanya keturunan Rasulullah dari jalur Fāṭimah dan 'Alī beserta keturunannya, tetapi juga siapa pun yang berikat darah atau perkawinan bersama Rasulullah. Dalam konteks ini yang termasuk abl al-bayt adalah keturunan Rasulullah, baik dari jalur Zaynab, Fāțimah, Ruqayyah dan Ummi Kulthum. Oleh karena itu, 'Uthman ibn 'Affān (Dqū al-Nürayn), 'Āishah binti Abū Bakr al-Șiddīq dan Hafșah binti 'Umar ibn al-Khațtab termasuk dalam kategori abl al-bayt karena mereka berdua adalah istri Rasulullah dan umm al-mukminin. Bagi kalangan Syiah, dua istri Rasulullah ini dianggap wanita kotor yang tidak layak mendampingi manusia terbaik di dunia dan akhirat. Wa al-Lāh a lam bi al-șawāb.

\section{Daftar Pustaka}

Abdullah. Risalah kepada Pecinta Abl al-bayt, Riyadh: Dar al Muntaqa.

Aḥmād, Imām, 1313 H. Al-Musnad, juz 3. Mesir: Dār al-Ma‘ārif. al-Alūsi, Sayyid Mạ̣mud Shukri. 1373 H. Mukhtasar al-Ṭhfah alIthnà 'Ashariyah. As-Salafiah.

al-'Āmilī, Shaikh Muhammad Hasan. 1391 H. Wasāil al-Shi'ah ilā Tashīl al-Masāil al-Sharíah. jilid 14. Kairo: Mathbū'āt alNajah.

'Irfān.

, 1357 H. al-Shi'ah wa al-Tashayyu'. ttp: Maṭa'ah al-

Asmuni, Yusran. 1996. Ilmu Taubid. Jakarta: Raja Grafindo Persada.

al-Gițā', Muḥammad Husain al-Kāshif. tt. Aṣlu al-Shīab wa Ușülubā. Kairo: al-Mațba'ah al-'Arabiyyah.

al-Halabi, Sulaiman. 1404 H. Ṭäifah al-Nusayriyah Tärikhubā wa 'Aqāidubā, Kuwait: al-Dār al-Salafiyah. 
Huzaemah. 1997. Perbandingan Madzhab. Jakarta: Logos.

Kermani, Abbas 'Affān. 2009. Kecuali Ali. Jakarta: Al-Huda.

al-Khātib, Muhib al-Dīn. 1394 H. Dzū al-Nurayn Uthmān ibn 'Affän. ttp: tp.

al-Khaui, Sayyid Abū al-Qāsim al-Musawa. 1390 H/1970 M. Mu'jäm Rijäl al-Hadith. Najf.

al-Khurasani, Muhammad 'Ali al-Khazimī. tt. Fawāid al-Ușūl alArba'ah. Teheran: Maktabah al-Ṣadr.

al-Makkī, Ahmad bin Hajar al-Haytami. Al-S awāiq al-Mubriqah fì al-Raddi 'alā Abl al-Bida' wa al-Zandaqah.

al-Musāwī, Ayatullah Sayyid Muḥammad. 2001. Maz̧bab Pecinta Keluarga Nabi, Kajian Al-Qur'an dan Sunnah. Jakarta: Al-Huda. al-Musawi, Sayyid Syafaruddin. 2010. Dialog Sunnab Ablus Sunnah-Syiah. Jakarta: Al-Huda.

al-Qummi, Abu al-Hasan 'Ali ibn Ibrāhim. 1386 H. Tafsir alQummi. Al-Jazairi: Mațba'ah al-Najaf.

al-Razil, Abū Ja'far ibn Ya'qūb ibn Ishāà al-Kulaini. tt. al-Käfi, Teheran: Dār al-Kutub al-Islamiyah.

Șadr, Muhammad Bāqir. 1385 H. Al-Ma'älim al-Jadìdah li al-Ușūl. Najf: Maṭba'ah Nu'mān.

al-Salus, 'Ali Ahmad. Fiqh al-Shi'ah al-Imāmiyyah wa Mawādi' alKhiläf Bainahu wa baina al-Madhahib al-Arba'ah. ttp: tp. 2011. Ensiklopedi Sunni Syiah Studi Perbandingan Akidah dan Tafsir, jilid 1. Jakarta: Pustaka Al-Kautsar. al-Ṣak'ah, Muṣtafā Muḥammad. 1994. Islām bilā Madhāhib, Jakarta: Gema Insani Press.

al-Shahrastānī, Abū al-Fatḥ Muhammad 'Abd al-Karīm ibn Bakr Ahmad, 1976. al-Milāl wa al-Nihäl. Beirut: Dār al-Fikr.

Staf Ahli Bidang Sosial Budaya BIN. 2008. Komunitas Syiah di Indonesia: Mengantisipasi potensi konflik yang Terpendam, Perspektif Historis dan Sosial Budaya. Jakarta: BIN RI.

al-Ṭabarasi, Abū Ali Faḍl ibn Hasan. 1379 H. Jawāmi’ al-Jami'. Iran: Maṭba'ah Mișbahi.

al-Ṭabarī, 1420 H. Tafsìr al-Ṭabari. jilid 8. ttp: Muassasah alRisālah.

al-Ṭabrasi, Husain ibn Muhammad Taqi al-Nūri. tt. Faṣl al-Khițāb fì Tahrîf Kitāb Rabb al-Arbāb. Hajar. 
Taimiyah, Ibn. 1406 H. Minhäj al-Sunnah al-Nabawiyyah. tahqiq Muhammad Rasyad Salim, Makkah: Jāmi'ah Imām Muhammad Ibn Su'ud.

al-Ṭusi, Abū Ja far Muḥammad ibn Hasan 1376 H. al-Tibyān. jilid 1.

Ṭuaimah, Șabir. 1983. Dirāsat fi al-Firaq. Riyaḍ: Maktabah alMa ārif.

Yaqin, Ainul (peny.). 2012. Fatwa MUI Provinsi Jawa Timur tentang Kesesatan Ajaran Syiah. Surabaya: MUI Provinsi Jawa Timur.

Jawa Pos, Rabu, 4 Januari 2012

Republika, 4 April 2012 